\title{
Microalgae Biomass Application in Commercial Broilers Nutrition and Their Efficacy Against Challenge with Epidemic Newcastle Disease Virus in Egypt
}

\author{
Sayeda Mohammed Abdo ${ }^{1 *}$, Sameh Abdel-Moez Amer ${ }^{2}$, Hagar Magdy Ahmed ${ }^{2}$, Rehab Hamdy Mahmoud ${ }^{1}$, \\ Abeer Abdallah Salama ${ }^{3}$ and Mohamed Abdel-Aziz Kutkat ${ }^{2}$ \\ ${ }^{I}$ Water Pollution Research Department, National Research Centre, Dokki, Cairo, Egypt. \\ ${ }^{2}$ Poultry Diseases Department, Veterinary Research Division, National Research Centre, Dokki, Cairo, Egypt. \\ ${ }^{3}$ Pharmacology department, National research centre, Giza, Egypt. \\ *Correspondence author’s Email: sayedamohammed2015@gmail.com; ORCID: 0000-0002-6416-3795
}

Received: 07 May 2019

Accepted: 04 June 2019

\begin{abstract}
Using microalgal biomass in animal diets has been studied recently. Many species of cultivated algae were found effective in maintaining animal growth performance, and in improving body weight. Using of microalgae collected from high rate algal ponds (HRAP) as a feed additive to broilers ration was studied. One hundred and twenty broiler chicks were divided into 6 groups of 20 birds, three of them have fed on balanced broiler ration supplied with $1 \%$ weight per weight (W/W) of microalgae biomass and have variable vaccination schemes of live attenuated and inactivated Newcastle disease virus (NDV) vaccines genotype II or either non-vaccinated control. In addition, the other 3 groups have fed on free microalgae biomass balanced ration with the same vaccination treatment. Furthermore, weight gain, antibody response, mortalities, viral shedding and normal viability of chickens were estimated in order to assess the efficiency of microalgae as a feed additive. The results showed that the microalgae have no hazard effect on feed and water intake as well as enhanced viability of chickens. And in regards to immune function and body weight, they have similar effect with the free microalgae groups in normal serological response and viral shedding post vaccination with NDV vaccines as well as similar protection rate and body weight gain. In conclusion, microalgae can be used in broiler ration with no deleterious effect on growth rate, weight gain, poultry viability and immune response. In conclusion dried microalgal biomass harvested from HRAP can be used in broiler ration with no deleterious effect on growth rate, weight gain, poultry viability and immune response. Furthermore, future studies should be applied with increasing microalgae percent in poultry feed up to 5,10 or $20 \%$ (W/W) in order to assess better performance on poultry production.
\end{abstract}

Key words: Algae biomass, Immune response, Newcastle disease virus, Poultry feed

\section{INTRODUCTION}

Microalgae considered as a good source of a wide range of metabolites that are suitable for animal feed. These metabolites include protein, carbohydrate, fat, vitamins, minerals, and other organic compounds (Abdelnour et al., 2019; Andrade et al., 2018). Microalgae are identified as microscopic, unicellular and photosynthetic organisms and can grow in saline and fresh water which are rich source of nutrients and biologically active compounds, including proteins, amino acids, polyunsaturated fatty acids (LCPUFA n-3), microelements, vitamins, antioxidants, as well as carotenoids which have a long history of application as a food for human (Belay et al., 1996). Microalgae of different species can be successfully included into poultry diets, for example as a defatted biomass byproduct from biofuel production, which can have a beneficial influence on birds' health, performance, and the quality of meat and egg (Abdelnour et al., 2019). Especially important for the poultry industry are recent studies where microalgal biomass was efficiently used in the production of eggs containing health-promoting lipids, i.e. eggs enriched with health promoting long-chain n-3 polyunsaturated fatty acids (LCPUFAs n-3) (Wu et al., 2012). Microalgae has many advantages including high growth rates, growth potential during the year and minimal land and water requirements compared to crop plants (Rawat et al., 2011). Furthermore, the high capital costs for large scale production of microalgal biofuel currently 
precludes this when coupled with wastewater treatment, it may become viable in the future (Rawat et al., 2011; Benemann, 2008).

High Rate Algal Ponds (HRAP) is an advanced open pond system that was found to offer more effective wastewater treatment technologies, since it performs high removal rates for nutrients, in addition to lower capital and operation costs, in comparison with traditional treatment ponds (Sutherland et al., 2014; Craggs et al., 2014). HRAP systems have the added advantage for resource recovery from the wastewater, via algal biomass, using as fertilizer, feed or as a feedstock for biofuel production, with the later use receiving considerable attention in recent years (Craggs et al., 2014; Park and Craggs, 2011).

Newcastle Disease Virus (NDV) causes one of the most important infectious diseases of poultry, Newcastle Disease (ND) found worldwide and causes losses from mortality and condemnation of carcasses (OIE, 2012). There are many countries that have endemic NDV, with increasing occurring year after year. Also known as avian paramyxovirus serotype-1 virus, NDV is a member of the genus Avulavirus in the Paramyxoviridae family (Mayo, 2002). Feeding of $\beta$-glucan derived from micro algae resulted asignificant increase in the antibody titer against NDV and Infectious Bronchitis Virus (IBV). It was suggested that dietary $\beta$-glucan and BA-pro might be useful in treating against viral diseases because of immunostimulating activity as reported by An et al. (2008).

The objective of the present study was to investigate the dietary effects of micro-algae biomass on growth performance, humoral immunity and viral shedding against challenge with velogenic NDV (VDNV) genotype VII in broiler chicks.

\section{MATERIALS AND METHODS}

\section{Ethical approval}

The animal experiment was conducted in strict accordance with and adherence to the relevant policies regarding animal handling as mandated under international national, and /or institutional guidelines for the care of animals and was approved by the research ethical committee at the national research centre, Cairo, Egypt.

\section{Algal biomass dominated by Microcystis sp.}

Race way-type pond (HRAP) made of glass-fiber reinforced plastics material, with $6.5 \mathrm{~m}^{3}$ capacity without connection or separation. Its dimensions are $7 \mathrm{~m}$ length $\times$ $3 \mathrm{~m}$ width $\times 40 \mathrm{~cm}$ depth and the effective wastewater depth is $0.3 \mathrm{~m}$. The HRAP was constructed and installed in Zenin wastewater treatment plant- Giza Company for water and wastewater (Figure 1). Algal biomass collected from HRAP $\left(1 \mathrm{~m}^{3}\right)$ is harvested biweekly and precipitated by cationic starch. Algal biomass was dried (using sun drier) and grinded to fine particles $(0.1 \mathrm{~mm})$.

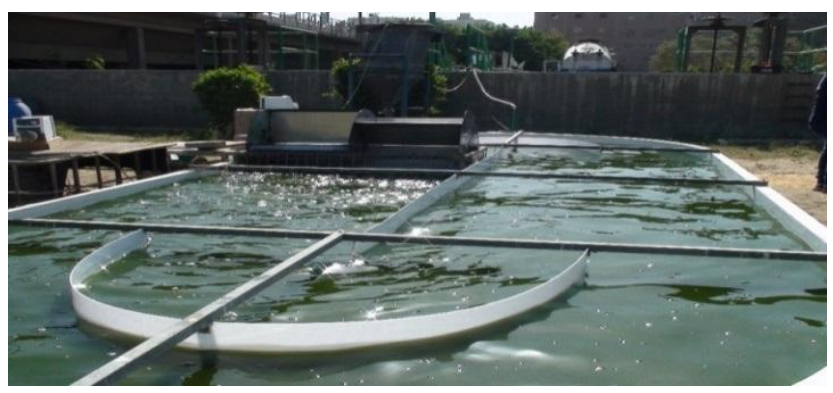

Figure 1. High rate algal pond system used for water treatment an algal biomass production

\section{Identification of algal community contained in the algal biomass}

Along one year, samples were collected twice a week and subsamples were dispensed into glass Sedgewick-Rafter cells and examined using OLYMPUS CX $41{ }^{\circledR}$ microscope (20xpower). Species composition and dominance in the samples were determined semiquantitatively. Algal identification has been done according to the main references used in phytoplankton identification (Streble and Krauter, 2006).

\section{Toxicity study for coagulants used in the precipitation of algae \\ Animals}

Thirty Swiss mice with $25 \mathrm{~g}$ average body weight were housed in standard cages (six rats), under specific pathogen-free conditions in facilities maintained at controlled room temperature $\left(21-24^{\circ} \mathrm{C}\right)$ with a $40-60 \%$ relative humidity and under normal environmental darklight cycles (from November to March, 7-9 hours of light and from April to October 9-12 hours of Light in Cairo, Egypt). All animals had free access to rat chow diet and water ad libitum and were acclimated for two weeks prior to initiation of the experiment in the laboratory of in the national research centre.

Acute toxicity study. Selected thirty mice of uniform weight are taken and divided into five groups each of six. The coagulants (cationic starches 1, 2, 3 and 4) and aluminum sulfate were dissolved in distilled water then given orally to four groups of mice in graded doses $(1 \mathrm{gm}$, $2 \mathrm{gm}, 3 \mathrm{gm} 4 \mathrm{gm}$ ) up to $5 \mathrm{~g} / \mathrm{kg}$ (El Naggar et al., 2018). In 
addition, the Non-Polar Fraction of dried Algal biomass (NPFA) was suspended in distilled water then given orally to rats in graded doses up to $5 \mathrm{~g} / \mathrm{kg}$. The control group received the same volumes of distilled water. The percentage mortality for extracts was recorded 24 hours later (Desoukey et al., 2016). Observation of rats for 14 days, for any changes in the skin and fur, respiratory, circulatory, autonomic, central nervous systems, somatomotor activity and behavior pattern. Particular observation for tremors, convulsions, salivation, diarrhea, lethargy, sleep, and coma were done (El Naggar et al., 2018).

Table 1. Composition of the experimental diets applied in broiler feed

\begin{tabular}{lcc}
\hline Item & $\begin{array}{c}\text { Starter } \\
(\mathbf{1} \text { to 21 day })\end{array}$ & $\begin{array}{c}\text { Grower } \\
(\mathbf{2 2} \text { to } \mathbf{4 0} \text { day })\end{array}$ \\
\hline Ingredient (\%) & & \\
Corn & 59.2 & 64.65 \\
Soybean meal & 30.0 & 24.0 \\
Corn gluten meal & 2.5 & 3.0 \\
Soybean oil & 2.8 & 3.0 \\
Limestone & 1.2 & 1.2 \\
Dicalcium phosphate & 1.7 & 1.6 \\
Vitamin-mineral premix & 1.0 & 1.0 \\
Salt & 0.3 & 0.3 \\
1-Lysine & 0.15 & 0.15 \\
dl-Methionine & 0.15 & 0.1 \\
Algae & 1.0 & 1.0 \\
\hline
\end{tabular}

\section{Analyzed chemical composition}

\begin{tabular}{|c|c|c|}
\hline $\mathrm{ME}(\mathrm{kcal} / \mathrm{kg})$ & 3,122 & 3,188 \\
\hline $\mathrm{CP}(\%)$ & 20.72 & 18.93 \\
\hline Ether extract (\%) & 4.14 & 5.79 \\
\hline $\mathrm{DM}(\%)$ & 89.1 & 88.4 \\
\hline Lysine (\%) & 1.17 & 1.0 \\
\hline Methionine (\%) & 0.5 & 0.41 \\
\hline Methionine + cysteine $(\%)$ & 0.65 & 0.6 \\
\hline Threonine $(\%)$ & 0.7 & 0.6 \\
\hline Tryptophan (\%) & 0.17 & 0.16 \\
\hline Calcium (\%) & 0.9 & 0.84 \\
\hline Phosphorus (\%) & 0.6 & 0.5 \\
\hline \multicolumn{3}{|c|}{$\begin{array}{l}\text { * Vitamin-mineral mix (per kilogram of diet): vitamin A: }(10000 \mathrm{IU} / \mathrm{g}) \\
8000 \mathrm{IU} \text {, vitamin D3: (200000 IU/g) } 1600 \mathrm{IU} \text {, vitamin E: }(20000 \mathrm{I} \mathrm{U} / \mathrm{g}) \\
11 \mathrm{mg} \text {, rboflavin: }(53 \mathrm{mg} / \mathrm{g}) 9 \mathrm{mg}, \alpha \text { calcium pantothenate: }(80 \mathrm{~g} / \mathrm{lb}) \text {, } \\
\text { vitamin B12: }(60 \mathrm{mg} / \mathrm{g}) 13 \mathrm{mg} \text {, niacin: } 26 \mathrm{mg} \text {; choline chloride: }(50 \%) \\
(74 \% \text { choline) } 900 \mathrm{mg} \text {, vitamin K: (Hetrazeen } 35.27 \mathrm{mg} / \mathrm{g}) 1.5 \mathrm{mg} \text {, folic } \\
\text { acid: }(13.23 \mathrm{mg} / \mathrm{g}) 1.5 \mathrm{mg} \text {, biotin: }(2 \%) 0.2 \mathrm{mg} \text {, santoquin: }(25 \%) 125 \\
\mathrm{mg} \text {, manganous oxide: }(56 \% \mathrm{Mn}) 55 \mathrm{mg} \text {, selenium premix: }(200 \mathrm{mg} / \mathrm{kg}) \\
0.1 \mathrm{mg} \text {, zinc oxide: }(80 \% \mathrm{Zn}) 50 \mathrm{mg} \text {, copper sulfate: }(25 \% \mathrm{Cu}) 5 \mathrm{mg} \text {, }\end{array}$} \\
\hline
\end{tabular}

ferrous oxide: $(69.94 \% \mathrm{Fe}) 30 \mathrm{mg}$, ME: (kcal/ $\mathrm{kg}$ ) metabolizable energy (kilocalorie per kilogram), CP: crude protein, DM: Dry matter

\section{Determination of carbohydrates content}

Total carbohydrate content of algal biomass was determined where $0.1 \mathrm{~g}$ of sample was treated with $25 \mathrm{ml}$ of 1 normal sulfuric acid $\left(1 \mathrm{~N} \mathrm{H}_{2} \mathrm{SO}_{4}\right)$ was added and the mixture was hydrolyzed for two hours on a boiling water bath. At the end of hydrolysis, a flocculent precipitate was noticed. This was freed of sulphate by precipitation with barium carbonate. The mixture was filtrated and completed to $100 \mathrm{ml}$. one $\mathrm{ml}$ of the filtrate mixed with one $\mathrm{ml} 5 \%$ phenol and $5 \mathrm{ml}$ concentrated $\mathrm{H}_{2} \mathrm{SO}_{4}$ (sulfuric acid). The absorbance was measured spectrophotometrically at wave length at $485 \mathrm{~nm}$ (Albalasmeh et al., 2013).

\section{Determination of total protein content}

Total protein content was determined by kjeldahl method and then multiplied with a factor of 6.25 to convert total measured organic nitrogen to total Protein to give the total protein (Stephen et al., 2013).

\section{Viruses and vaccines}

Challenge virus. Very Virulent (vv) NDV used in the challenge was kindly supplied by poultry diseases department, veterinary research division, National Research Centre, Dokki, Egypt, characterized by sequencing as vvNDV genotype VIId designated as NDV/Chicken/EG-MN/NRC/2015 under accession number (MF418020.1) on gene bank. The virus challenge dose equal 6-Log-10 EID $_{50}$ given $0.5 \mathrm{ml} /$ bird via Intramuscular route (IM) (OIE, 2012).

Live NDV vaccine. Freeze-dried vaccine containing live NDV LaSota strain (Jovac ND LaSota ${ }^{\circledR} 1000$ doses, Jordan) supplied by local agency. The vaccinal dose equal $6-\mathrm{Log}^{-10} \mathrm{EID}_{50} /$ bird was given via occulonasal route as recommended by manufacturer.

Inactivated NDV genotype II vaccine. Inactivated NDV genotype II vaccine (Boehringer Ingelheim ${ }^{\circledR}$ AI ND 1000 doses, Germany) supplied by local agency. The vaccinal dose equal 8.2-Log-10 EID $_{50}$ given $0.5 \mathrm{ml} /$ bird via subcutaneous route (SC) as recommended by manufacturer.

\section{Serology}

Blood was collected pre and post challenge from all birds at 14, 21, 28 and 35 days of age, serum was extracted then tested by Hemagglutination Inhibition (HI) assay. The HI assay was performed using LaSota NDV antigen 
according to standard procedures with four haemagglutination units virus/antigen in $0.025 \mathrm{ml}$ (OIE, 2012).

\section{Virus shedding}

Virus Isolation (VI) was performed to identify virus shedding conducted on oral and cloacal swabs as All VIpositive swabs were titrated in 9-11 days old specific pathogen free embryonated chicken eggs. Virus titers were calculated reported as mean embryo infectious dose $\left(\mathrm{EID}_{\mathbf{5 0}} / 0.1 \mathrm{ml}\right)$ on a Log 10 scale (OIE, 2012).

Table 2. Experimental design for usages of microalgae biomass in Broilers diet treated with different vaccines of Newcastle disease against velogenic Newcastle disease virus challenge

\begin{tabular}{|c|c|c|c|c|c|}
\hline \multirow{2}{*}{$\begin{array}{l}\text { Group } \\
\text { no. }\end{array}$} & \multirow{2}{*}{$\begin{array}{l}\text { Birds } \\
\text { no. }\end{array}$} & \multicolumn{2}{|c|}{ Vaccination regime } & \multirow{2}{*}{$\begin{array}{c}\text { Microalgae } \\
\text { Addition with } 1 \% \\
\text { In feed }\end{array}$} & \multirow{2}{*}{ Challenge at age / day ${ }^{c}$} \\
\hline & & Type & Age / days & & \\
\hline 1 & 20 & Live GII $^{a}$ & 5 and 18 & + & 28 \\
\hline 2 & 20 & $\begin{array}{c}\text { Live. GII } \\
\text { Inact.NDV.GII }^{\text {b }}\end{array}$ & $\begin{array}{c}5 \text { and } \\
7\end{array}$ & + & 28 \\
\hline 3 & 20 & None & None & + & 28 \\
\hline 4 & 20 & Live GII & 5 and 18 & None & 28 \\
\hline 5 & 20 & $\begin{array}{c}\text { Live. GII } \\
\text { Inact.NDV GII }\end{array}$ & $\begin{array}{l}5 \text { and } 18 \\
7\end{array}$ & None & 28 \\
\hline 6 & 20 & None & None & None & 28 \\
\hline
\end{tabular}

$\overline{{ }^{a}}$ Live NDV vaccine genotype II (LaSota strain). The vaccinal dose equal 6- $\log _{-10} \mathrm{EID}_{50} /$ bird given via occulonasal route, ${ }^{\mathbf{b}}$ Inactivated oil emulsion NDV vaccine genotype II (LaSota strain). The vaccinal dose equal 8.2- $\log _{-10} \mathrm{EID}_{50}$ given $0.5 \mathrm{ml} /$ bird via $\mathrm{SC}$ route, ${ }^{\mathbf{c}}$ Challenge with velogenic Newcastle disease virus (genotype VII). The virus challenge dose equal 6-Log-10 EID $_{50}$ given $0.5 \mathrm{ml} /$ bird via IM route. no: number

\section{RESULTS}

\section{Algal dynamics and predominance in the high rate algal pond}

The high rate algal pond operation started on 30 June 2017 (summer months) which lead to the predominance of Microcystis flos aquae, Microcystis aeruginosa and other species of Microcystis. Always, different Microcystis sp. represent the upper most layer, while near the bottom layer of the pond different green and diatoms group are present. Many species include Scenedesmus obliquus and Scenedesmus quadricauda, Ankistrodesmus, Coelastrum microporum, Selenastrum and Micractinium pusillum (green algae group), Oscillatoria limnetica (blue green algae group) and Nitzschia linearis (diatoms group) was the most pre dominant species. Since the beginning of November 2017, the community structure of HRAP completely changed where the Microcystis sp. disappeared and the dominance of different algal species took place. In addition, all algal species mixed and floated in pond

\section{Experimental design}

One hundred and twenty broiler chicks (Cobb 500®) one day-old supplied from commercial hatchery, were divided into six groups of 20 birds in separate units with strict biosecurity level. Conventional animal welfare regulations and food standards were taken into account (Table 2). 
obvious changes were detected in skin and fur, respiratory, circulatory, autonomic, central nervous systems, as well as somatomotor activity and behavioral pattern were apparently normal.

Proteins and carbohydrates content were detected in order to evaluate the possibility of using the biomass for feeding properties. Total protein content detected was ranging from 232.1 to $371.3 \mathrm{mg} / \mathrm{gm}$. Referring to carbohydrates content, total carbohydrates content was ranged from 100-138 mg/gm. Microalgae was reported to have high percentage of proteins, lipids and carbohydrates and could be used in the manufacture of different products. Microalgae can be grown in open ponds or closed photobioreactors (Kit et al., 2017; Koopmans, 2013).

\section{Serological response and hemagglutination inhibition assay}

Similar immunological response was detected between treated and non-treated algae groups. HI geometric means titers were ranged from 2.81 to 5.43 versus 2.83 to $5.23 \mathrm{HI}$ titers in $\mathrm{G} 1$ and $\mathrm{G} 4$, respectively. While, ranged from 3.93 to 6.64 versus 3.86 to $6.61 \mathrm{HI}$ titers in G2 and G5, respectively. Whereas, nonvaccinated infected controls G3 and G6 were, 1.73 to 1.91 HI titers against 1.36 to $1.86 \mathrm{HI}$ titers, respectively before and after challenge (Table 3 ).

Table 3. Serological response of different vaccines against velogenic Newcastle disease virus challenge after algal biomass addition in broilers diet

\begin{tabular}{|c|c|c|c|c|c|c|c|c|c|}
\hline \multirow{3}{*}{$\begin{array}{l}\text { Group } \\
\text { no. }\end{array}$} & \multirow{3}{*}{$\begin{array}{l}\text { Birds } \\
\text { no. }\end{array}$} & \multicolumn{2}{|c|}{ Vaccination regime } & \multirow{3}{*}{$\begin{array}{l}\text { Microalgae } \\
\text { Addition with } \\
1 \% \text { In feed }\end{array}$} & \multirow{3}{*}{$\begin{array}{l}\text { Challenge at } \\
\text { age/day }\end{array}$} & \multicolumn{4}{|c|}{$\begin{array}{l}\text { HI }^{d} \text { titre means Log-2 at age/days } \\
\qquad(\mathrm{N}=5)\end{array}$} \\
\hline & & \multirow{2}{*}{ Type } & \multirow{2}{*}{ age/days } & & & & & & \\
\hline & & & & & & 14 & 21 & 28 & 35 \\
\hline 1 & 20 & Live GII $^{a}$ & 5 and 18 & + & 28 & 2.81 & 3.56 & 4.42 & 5.43 \\
\hline 2 & 20 & $\begin{array}{c}\text { Live GII } \\
\text { Inact.NDV GII }^{\text {b }}\end{array}$ & $\begin{array}{c}5 \text { and } 18 \\
7\end{array}$ & + & 28 & 3.93 & 4.86 & 5.21 & 6.64 \\
\hline 3 & 20 & None & None & + & 28 & 1.73 & 1.61 & 1.91 & NT \\
\hline 4 & 20 & Live GII & 5 and 18 & None & 28 & 2.83 & 3.61 & 4.33 & 5.23 \\
\hline 5 & 20 & $\begin{array}{c}\text { Live GII } \\
\text { Inact.NDV GII }\end{array}$ & $\begin{array}{c}5 \& 18 \\
7 \\
\end{array}$ & None & 28 & 3.86 & 4.52 & 5.36 & 6.61 \\
\hline 6 & 20 & None & None & None & 28 & 1.36 & 1.65 & 1.86 & NT \\
\hline
\end{tabular}

\section{Protection from clinical disease and post-mortem} gross lesions

The objective of this study was to estimate the effect of microalgae in poultry feed on viability, weight gain and enhancement of immune response and lesser shedding of viral infection that already circulated in field. Accordingly, chickens in all groups were monitored for one-week PostChallenge (PCH). Vaccinated-challenged groups (G1, G2, G4 and G5 either with or without algae in feed, respectively) indicated similar degree of protection against clinical disease in the form of mild respiratory signs, dull appearance and decreased in feed and water intakes for three days of $\mathrm{PCH}$. While non-vaccinated-challenged groups (G3 and G6 with or without algae in feed, respectively) showed more severe signs of foamy conjunctivitis, swollen eye lids, respiratory sounds, slight depression and marked decrease in feed and water intake. Obvious greenish diarrhea, marked depression with sleepy appearance at three days PCH. Severe respiratory sounds, conjunctivitis, nasal discharge four days $\mathrm{PCH}$, and paresis ended by nervous signs (torticollis) seven days PCH.

On the other side, all dead birds were necropsied for Post-Mortem (pm) gross lesions assays revealed that, vaccinated-challenged birds showed mottled and enlarged spleens with either hemorrhagic spots and/or petechial hemorrhages on the proventricular glands (Figure 2). While non-vaccinated infected controls had severe pm gross lesions including severe congestion in the trachea, necrosis and congestion of liver, mottled and enlarged spleen, either hemorrhagic spots and/or petechial hemorrhages on the proventricular glands and enteritis with greenish intestinal contents (Figure 2).

\section{Body weight value of microalgae}

Since the nutritional value of microalgae varies considerably with the species used, $1 \%$ treated algae ration was not enough to add value in compare with non-treated groups (Table 4). The G1 average Body Weight (BW) in 
compared with G4 was $1.43 \mathrm{~kg}$ versus $1.46 \mathrm{~kg}$, respectively. Whereas, G2 in compared with G5 was 1.41 versus $1.42 \mathrm{~kg}$, respectively. Furthermore, non-vaccinated controls G3 1.3 versus G6 $1.25 \mathrm{~kg}$, respectively all at 28 days of age. In addition to, viability of chickens and rate of feed and water consumption was nearly equal and in normal if comparing algae and non-algae treated groups.

\section{Protection against mortalities}

One of the major purposes of this study was to determine the role of micro algae treated ration in enhancement of better viability and fair protection against mortalities when challenge birds with vvNDV post vaccination regimes. Table 5 indicates $95 \%$ of nonvaccinated infected controls were dead at one week $\mathrm{PCH}$ in both G3 and G6. While, mortalities in G1 compared with G4 was $60 \%$ versus $55 \%$, respectively. Furthermore, was $25 \%$ in both $\mathrm{G} 2$ and G5 one week PCH.

\section{Virus shedding}

Viral shedding is one of the most relevant parameter in judgment of vaccine efficacy in correlation with the differences in immunological response obtained from microalgae supplement. Accordingly, No obvious differences were detected in bio-algae feeded groups in compared with non-feeded ones. Viral titers ( $\log 10)$ expressed as mean embryo infectious doses per $0.1 \mathrm{ml}$ in G1 against G4 were 4.1 and 5.7 versus 4.2 and 5.6, respectively at three and seven days $\mathrm{PCH}$. While, in G2 and G5 were 2.9 and 4.1 versus 2.8 and 4.2, respectively at three and seven days PCH. In addition, viral titer was 6.5 in both non-vaccinated challenged controls (G3 and G6) three days PCH (Table 6 and Figure 4).

Table 4. Weight gain after algal biomass addition in broilers diet treated with different vaccines against velogenic Newcastle disease virus challenge

\begin{tabular}{|c|c|c|c|c|c|c|}
\hline $\begin{array}{l}\text { Group } \\
\text { no. }\end{array}$ & Birds no. & \multicolumn{2}{|c|}{ Vaccination regime } & $\begin{array}{l}\text { Microalgae } \\
\text { Addition with } \\
1 \% \text { In feed }\end{array}$ & $\begin{array}{l}\text { Challenge at } \\
\text { age / day c }\end{array}$ & $\begin{array}{c}\text { Average BW in } \\
\text { kilograms at } 28 \\
\text { days of age }\end{array}$ \\
\hline 1 & 20 & Live GII $^{a}$ & 5 and 18 & + & 28 & 1.43 \\
\hline 2 & 20 & $\begin{array}{c}\text { Live GII } \\
\text { Inactivated NDV GII }^{\mathrm{b}}\end{array}$ & $\begin{array}{c}5 \text { and } 18 \\
7\end{array}$ & + & 28 & 1.41 \\
\hline 5 & 20 & $\begin{array}{c}\text { Live GII } \\
\text { Inactivated .NDV GII }\end{array}$ & $\begin{array}{c}5 \text { and } 18 \\
7\end{array}$ & None & 28 & 1.42 \\
\hline 6 & 20 & None & None & None & 28 & 1.25 \\
\hline
\end{tabular}

Table 5. Mortality percent after algal biomass addition in broilers diet treated with different vaccines against velogenic Newcastle disease virus challenge

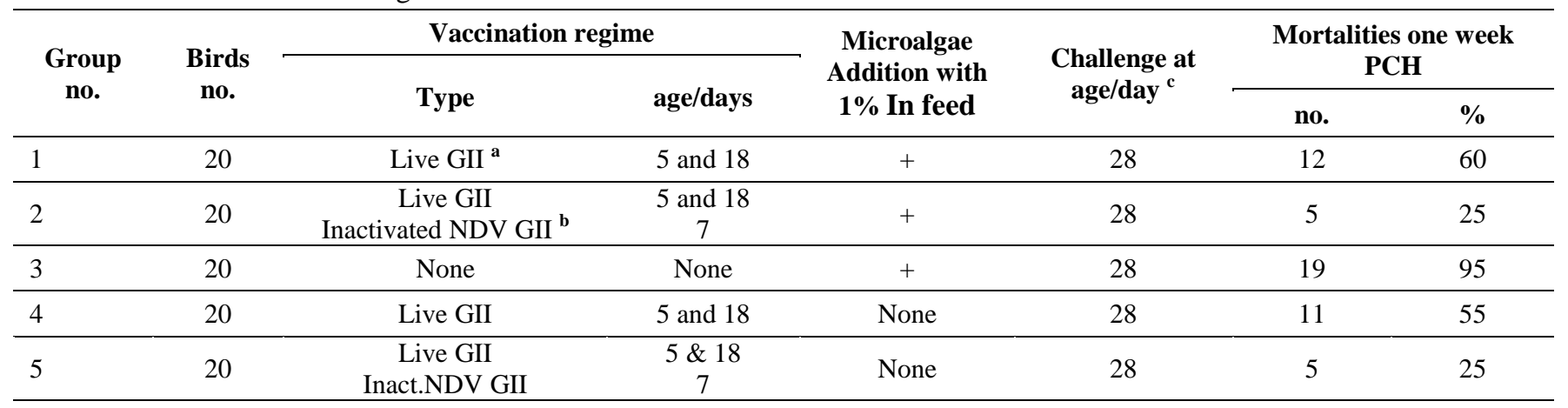




\begin{tabular}{|c|c|c|c|c|c|c|c|}
\hline 6 & 20 & None & None & None & 28 & 19 & 95 \\
\hline $\begin{array}{l}{ }^{2} \text { Live ND } \\
\text { II. The va } \\
\text { VII). The } \\
\text { Table } 6 \\
\text { Newcas }\end{array}$ & $\begin{array}{l}\text { cine LaSo } \\
\text { dose equ } \\
\text { challenge } \\
\text { ral she } \\
\text { sease vi }\end{array}$ & $\begin{array}{l}\text { train. The vaccinal dose eq } \\
2 \text {-Log-10 } \text { EID }_{50} \text { given } 0.5 \\
\text { e equal 6-Log-10 EID50 gi } \\
\text { ng after algal bioma } \\
\text { challenge }\end{array}$ & $\begin{array}{l}\log _{-10} \mathrm{EID}_{50} / \\
\text { ird via subcu } \\
5 \mathrm{ml} / \text { bird vi } \\
\text { ddition in }\end{array}$ & $\begin{array}{l}\text { iven via occulona } \\
\text { us route }(\mathrm{S} / \mathrm{C}) .{ }^{\mathrm{c}} \mathrm{Cl} \\
\text { amuscular route. } \mathrm{P} \\
\text { ilers diet treat }\end{array}$ & $\begin{array}{l}\text { oute. }{ }^{\mathrm{b}} \text { Inactiva } \\
\text { enge with velos } \\
\text { post challenge } \\
\text { with differ }\end{array}$ & $\begin{array}{l}11 \text { emulsion NI } \\
\text { Newcastle dis } \\
\text { Number. } \\
\text { vaccines a }\end{array}$ & $\begin{array}{l}\text { vaccine genotyp } \\
\text { virus (genotyp } \\
\text { nst velogeni }\end{array}$ \\
\hline \multirow{2}{*}{$\begin{array}{l}\text { Group } \\
\text { no. }\end{array}$} & \multirow{2}{*}{$\begin{array}{c}\text { Birds } \\
\text { no. }\end{array}$} & \multicolumn{2}{|c|}{ Vaccination regime } & \multirow{2}{*}{$\begin{array}{l}\text { Microalgae } \\
\text { Addition with } \\
1 \% \text { In feed }\end{array}$} & \multirow{2}{*}{$\begin{array}{c}\text { Challenge at } \\
\text { age/day }\end{array}$} & \multicolumn{2}{|c|}{$\begin{array}{c}{ }^{\mathrm{d}} \text { Shedding at days post- } \\
\text { challenge }\end{array}$} \\
\hline & & Type & age/days & & & $\begin{array}{c}3 \text { days } \\
\text { (OP swabs) }\end{array}$ & $\begin{array}{c}7 \text { days } \\
(\mathrm{CL} \text { swabs })\end{array}$ \\
\hline 1 & 20 & Live GII $^{a}$ & 5 and 18 & + & 28 & 4.1 & 5.7 \\
\hline 2 & 20 & $\begin{array}{c}\text { Live GII } \\
\text { Inactivated NDV GII }^{\mathbf{b}}\end{array}$ & $\begin{array}{c}5 \text { and } 18 \\
7\end{array}$ & + & 28 & 2.9 & 4.1 \\
\hline 3 & 20 & None & None & + & 28 & 6.5 & NT \\
\hline 4 & 20 & Live GII & 5 and 18 & None & 28 & 4.2 & 5.6 \\
\hline 5 & 20 & $\begin{array}{c}\text { Live GII } \\
\text { Inact.NDV GII }\end{array}$ & $\begin{array}{c}5 \& 18 \\
7\end{array}$ & None & 28 & 4.8 & 4.2 \\
\hline 6 & 20 & None & None & None & 28 & 6.5 & NT \\
\hline
\end{tabular}

${ }^{a}$ Live NDV vaccine LaSota strain. The vaccinal dose equal 6-log-10 EID $_{50} /$ bird given via occulonasal route, ${ }^{\mathbf{b}}$ Inactivated oil emulsion NDV vaccine genotype II. The vaccinal dose equal 8.2- $\log _{-10} \mathrm{EID}_{50}$ given $0.5 \mathrm{ml} /$ bird via subcutaneous route, ${ }^{\mathbf{c}}$ Challenge with velogenic Newcastle disease virus (genotype VII). The virus challenge dose equal 6- $\log _{-10} \mathrm{EID}_{50}$ given $0.5 \mathrm{ml} / \mathrm{bird}$ via intramuscular route, ${ }^{\mathrm{d}}$ Viral titers (log 10) expressed as mean embryo infectious doses per $0.1 \mathrm{ml}$ from oral and cloacal swabs taken at day 3 and 7 post-challenge from the challenged birds. OP: oropharyngeal, CL: cloacal, NT: None tested, no: number of birds in each group.
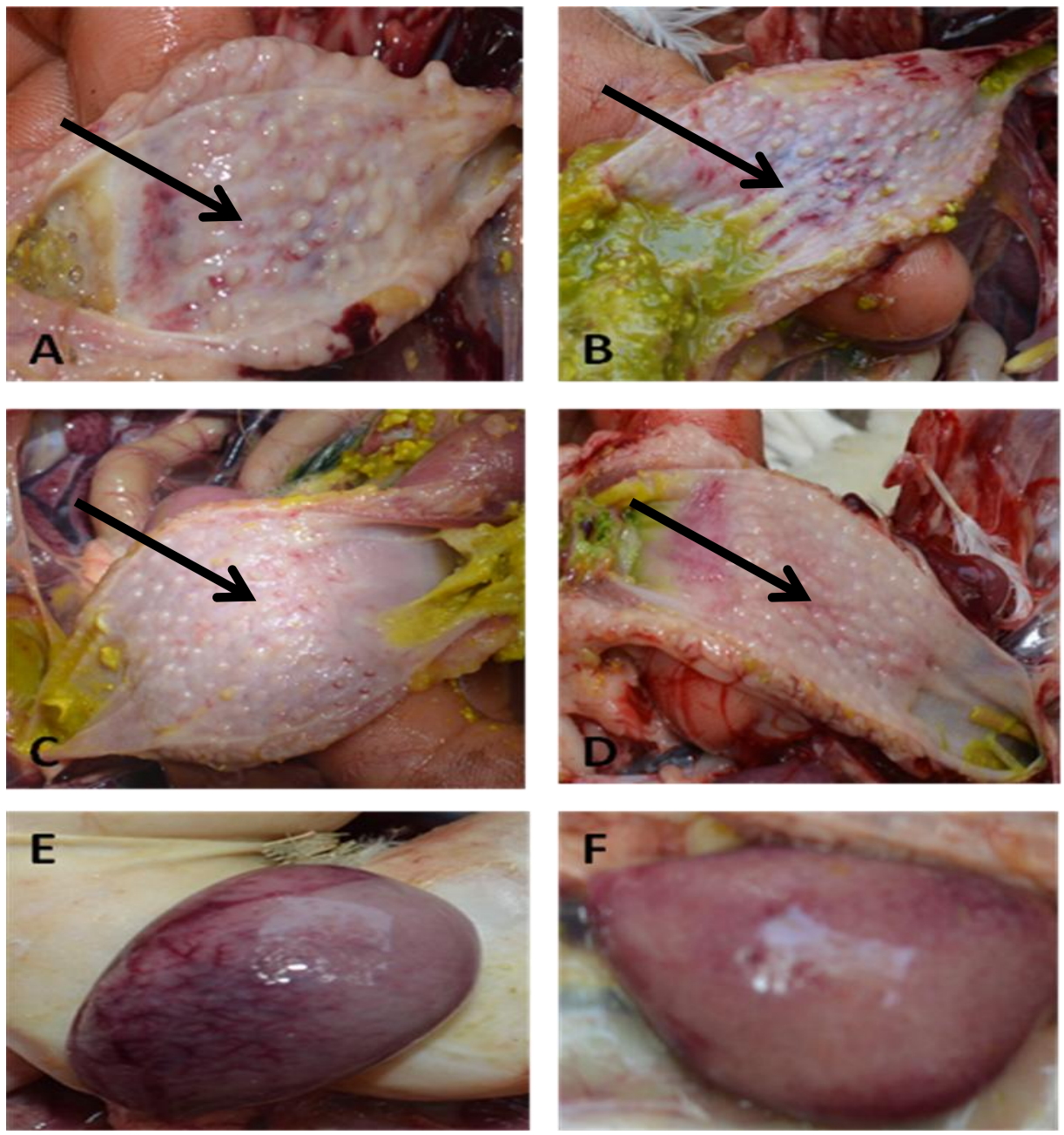
Figure 2. The post mortem lesions in broiler chickens treated with different vaccines of Newcastle disease against velogenic Newcastle disease virus challenge. A and B: Petechial hemorrhage on proventricular glands of infected controls Groups 3 and 6 , respectively at 4 days after challenge. C and D: petechial hemorrhage on proventricular glands of infected vaccinates Groups 2 and 5, respectively at 5 days after challenge. $\mathbf{E}$ and $\mathbf{F}$ : mottled and enlarged spleen of infected vaccinates groups 1 and 4 , respectively at 5 days after challenge.

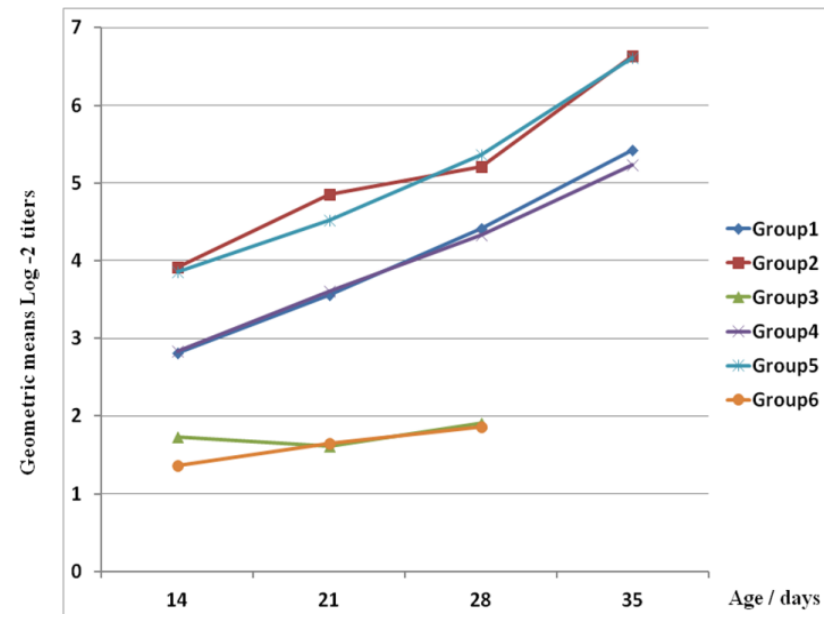

Figure 3. Serological response evaluation after microalgae biomass application in commercial broilers feed and received different Newcastle disease virus vaccination schemes against velogenic Newcastle disease virus challenge at 14, 21, 28 and 35 days post challenge with haemagglutination titers of the same rang of both algae-treated groups or no-algae feeded ones either challenged or non-infected controls.

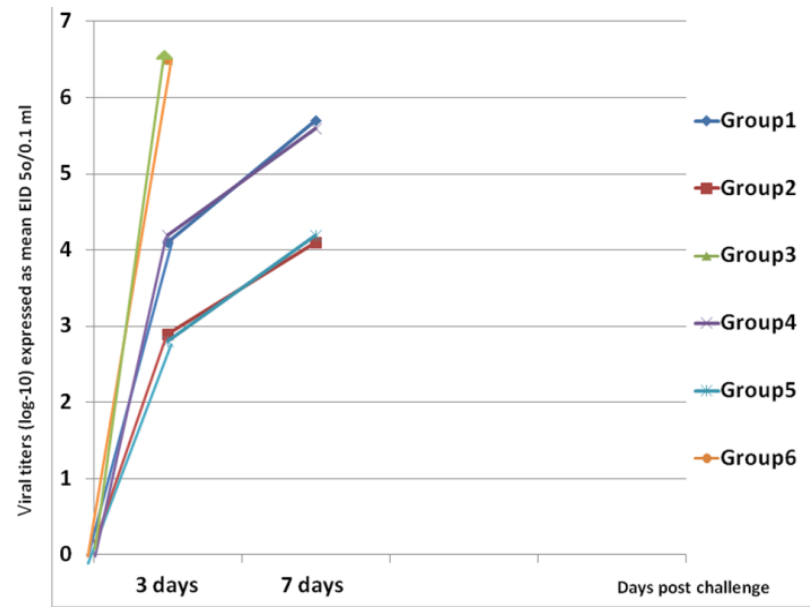

Figure 4. Viral shedding after velogenic Newcastle disease virus challenge at 3 and 7 days from oropharyngeal and cloacal swabs for evaluation of microalgae biomass application effect in commercial broilers feed treated with different Newcastle disease virus vaccination schemes. Showing viral titers of the same rang of both algae-treated groups or no-algae feeded ones either challenged or non-infected controls.

\section{DISCUSSION}

Using microalgal biomass in feeding animals has recently applied in poultry as Microalgae improve skin color, shanks and egg yolks. Numerous nutritional and toxicological evaluations revealed the appropriateness of algal biomass as a valuable feed supplement or used instead of conventional protein sources (soybean meal, fish meal, rice bran, etc.) (Becker, 2007). In addition to, using algae as a protein source for livestock, many were used for health benefits (i.e. improved immune response, improved fertility, better weight control, healthier skin and a lustrous coat) (Pulz and Gross, 2004).

This study aims to explore the effects of dietary micro algae supplementation in broiler chicks as enhancer of BW and immune status in broilers in a challenged setting. No considerable differences were found in BW among the treatment groups with $1 \%$ bioalgae supplement (Andrade, 2018; Abdelnour et al., 2019). Nonetheless earlier studies have reported changeable results debating the effects of micro algae on performance in poultry. Zhang et al. (2008) found that $\beta$-glucans extracted from the algae at the percentage of 50 and $75 \mathrm{mg} / \mathrm{kg}$ in the diet increased BW. In a similar work, (Rathgeber et al., 2008) observed higher $\mathrm{BW}$ in broilers that fed on $\beta$-glucan during the growth phase. On the other hand, other researchers reported low performance after B-glucan supplementation in chickens (Huff et al., 2006). In harmony with our findings, several cases reported no significant effects of micro algae on growth performance where algae feeding do not negatively affect performance in either non-challenged reports (Cheng et al., 2004; Chae et al., 2006; Morales-Lopez et al., 2009) or challenged settings (Chen et al., 2006; Chen et al., 2008). The conflicting results found in those studies could be due to differences in the source of the algae or the presence and type of challenge used, or both.

The use of live and inactivated vaccines has been used in the prevention and control of NDV (Zhao et al., 2014). Vaccines induce antibody production of $\operatorname{IgA}, \mathrm{IgG}$, and IgM to high levels of vaccinated chicks (Russell and Ezeifka, 1995). Because micro algae can play a role in stimulating these immune responses, the use of algae products in poultry vaccinated with NDV has been studied. In a study by An et al. (2008), algal B-glucan was fed to NDV vaccinated broilers at levels of $0,0.025$, and $0.1 \%$ for 35 days. The inclusion of algal B -glucan 
significantly increased $(\mathrm{P}<0.05)$ at day $35 \mathrm{BW}$ of NDV vaccinated broilers than control. Additionally, NDV specific antibody titers were elevated through the supplementation of algal B-glucan at $0.1 \%$. The cell mediated immune response was suggested by (Cheng et al., 2004) to be improved by algal $\beta$-glucan through modulating macrophage activity. These observations are supported by (An et al., 2008) who also observed an increase in day 35 Newcastle virus antibody titers when feeding algal B-glucan at 0.05 and $0.1 \%$, suggesting dosage level of $\beta$-glucan impacted the increase in antibody titers. These data confirm that an algal supplement can improve early performance parameters in a non-challenge setting, increase Newcastle virus specific antibody titers, and eliminate growth performance reductions in Eimeria challenged broilers. These data also confirm that dosage level of algae plays a significant role in performance effects in both non-challenged and challenged settings. These three experiments demonstrate the effectiveness of micro algae in poultry production although additional research must be conducted to further confirm proper dosage level. The results of Morales-Lopez et al. (2009) supporting our results, revealing that no benefits to performance or NDV specific antibody titers of a purified algae when fed to NDV vaccinated broilers.

In recent work and in agreement with our study Evans et al. (2015) showed that the incorporation of $16 \%$ of dried algae into a broiler diet has no negative effects on the performance of chicks. In addition, (Ross and Dominy, 1990) showed similar results in his work where found that no significant differences in performance of broilers fed a diet containing 1.5, 3, 6 or 12\% dehydrated algae in feed. As well as, (Raach-Moujahed et al., 2011) also reported that fed with or without 4 or $8 \%$ of algal biomass in the diet has no difference in growth performance of broilers. In contrast, (Shanmugapriya et al., 2015) recently observed improvement in body weight gain and food conversion rate in broilers when fed a diet with algal biomass. Furthermore, Mariey et al. (2012) reported that including algal biomass in low concentration $(0.02$ or $0.03 \%$ ) not only improved performance in broilers, but also increased dressing percentage, meat color score, blood morphology was improved and relative abdominal fat weight was decreased.

A lot of projects in many countries are going on since the algal biomass production has concerned, currently there are lot of projects going on in many countries. We concluded that, the present study has established the safety and acceptability of micro algae biomass as poultry feed up to $1 \%$ replacement and may be incorporated into practical broiler diets that utilized by broiler chicks without causing detriment to performance, immunity or either viability and body weight gain. So as to, further research is required to identify the optimal dosage of microalgal biomass supplementation for consistent favorable results in poultry.

\section{DECLARATIONS}

\section{Acknowledgments}

The authors sincerely thank the academy of scientific research and technology, ministry of higher education, Egypt, for the kind support and providing infrastructure facilities to carry out this work. This work was developed within the scope of the financed project entitled "novel approach to maximize the use of stabilization pond in Egypt: A model for water and energy food nexuses" ID: 1343.

\section{Author's contribution}

Sayeda, Sameh, Hagar, Rehab, Abeer and Mohamed Kutkat participated in design, experimental procedure, writing, revised, and reviewing the manuscript.

\section{Competing interests} interest exists

The authors have declared that no competing

\section{Consent to publish}

The authors guarantee that this work has not been published elsewhere and that any person named as a coauthor of this work is aware of the fact and has agreed to be so named.

\section{REFERENCES}

Abdelnour SA, Abd El-Hack ME, Arif M, Khafaga AF and Taha AE (2019). The application of the microalgae Chlorella spp. as a supplement in broiler feed. World's Poultry Science Journal, 1-14. DOI:https://doi.org/10.1017/S0043933919000047.

Albalasmeh AA, Berhe AA and Ghezzehei TA (2013). A new method for rapid determination of carbohydrate and total carbon concentrations using UV spectrophotometry. Carbohydrate Polymers, 97 (2): 253-261. DOI:https://doi.org/10.1016/j.carbpol.2013.04.072

An BK, Cho BL, You SJ, Paik HD, Chang HI, Kim SW and Kang CW (2008). Growth performance and antibody response of broiler chicks fed yeast derived $\beta$-glucan and single-strain probiotics. Asian-Australasian Journal of Animal Sciences, 21(7):1027-1032. DOI:https://doi.org/10.5713/ajas.2008.70571

Andrade LM (2018). Chlorella and Spirulina Microalgae as Sources of Functional Foods, Nutraceuticals, and Food Supplements; an Overview. MOJ Food Processing \& 
Technology,

6(1):

DOI:https://doi.org/10.15406/mojfpt.2018.06.00144

Becker EW (2007). Micro-algae as a source of protein. Biotechnology Advances, 25(2): 207-210. DOI:https://doi.org/10.1016/j.biotechadv.2006.11.002

Belay A, Kato T and Ota Y (1996). Spirulina (Arthrospira): Potential application as an animal feed supplement. Journal of Applied Phycology, 8(4-5): 303-311. DOI:https://doi.org/10.1007/BF02178573

Benemann JR (2008). Opportunities and Challenges in Algae Biofuels Production. Algae, 1-15.

Chae BJ, Lohakare JD, Moon WK, Lee SL, Park YH and Hahn TW (2006). Effects of supplementation of $\beta$-glucan on the growth performance and immunity in broilers. Research in Veterinary Science, 80(3): 291-298. DOI:https://doi.org/10.1016/j.rvsc.2005.07.008.

Chapman HD and Pratt PF (1978). Methods of Analysis for Soils, Plants and Waters, pp: 50 Univ. of California Division of Agricultural Science, Priced Publication, 4034.

Chen KL, Weng BC, Chang MT, Liao YH, Chen TT and Chu C (2008). Direct enhancement of the phagocytic and bactericidal capability of abdominal macrophage of chicks by $\beta-1,3-1,6-G l u c a n$. Poultry Science, 87(11): 2242-2249. DOI:https://doi.org/10.3382/ps.2008-00147.

Chen TT, Tsay SM, Yu CY, Weng BC and Chen KL (2006). Effects of dietary $\beta$-glucan supplementation against Eimeria tenella infection and immune parameter in male leghorn chicks. Journal of the Chinese Society of Animal Science, 35:101-108.

Cheng YH, Lee DN, Wen CM and Weng CF (2004). Effects of $\beta$-glucan supplementation on lymphocyte proliferation, macrophage chemotaxis and specific immune responses in broilers. Asian-Australasian Journal of Animal Sciences, 17(8): $1145-1149$. DOI:https://doi.org/10.5713/ajas.2004.1145.

Chew KW, Yap JY, Show PL, Suan NH, Juan JC, Ling TC and Chang JS (2017). Microalgae biorefinery: High value products perspectives. Bioresource Technology, 229: 5362. DOI: https://doi.org/10.1016/j.biortech.01.006.

Craggs R, Park J, Heubeck S and Sutherland D (2014). High rate algal pond systems for low-energy wastewater treatment, nutrient recovery and energy production. New Zealand Journal of Botany, 52(1): 60-73. DOI:https://doi.org/10.1080/0028825X.2013.861855.

Desoukey SY, El Kady WM, Salama AA, Hagag EG, ElShenawy SM and El-Shanawany MA (2016). Hepatoprotection and antioxidant activity of Gazania longiscapa and $\mathrm{G}$. rigens with the isolation and quantitative analysis of bioactive metabolites. International Journal of Pharmacognosy and Phytochemical Research, 8(7): 1121-1131.

El-Naggar ME, Samhan FA, Salama AA, Hamdy RM and Ali GH (2018). Cationic starch: Safe and economic harvesting flocculant for microalgal biomass and inhibiting E. coli growth. International Journal of Biological Macromolecules, 116(May): 1296-1303. DOI:https://doi.org/10.1016/j.ijbiomac.2018.05.105.
Evans AM, Smith DL and Moritz JS (2015). Effects of algae incorporation into broiler starter diet formulations on nutrient digestibility and 3 to $21 \mathrm{~d}$ bird performance. Journal of Applied Poultry Research, 24(2): 206-214. DOI:https://doi.org/10.3382/japr/pfv027.

Huff GR, Huff WE, Rath NC and Tellez G (2005). IMMUNOLOGY , HEALTH , AND DISEASE Limited Treatment with $\beta-1$, 3 / 1 , 6-Glucan Improves Production Values of Broiler Chickens Challenged with Escherichia coli. Poultry Science, 613-618.

Mariey YA, Samak H and Ibrahem M (2012). Effect of using spirulina platensis algae as afeed additive for poulrty diets: 1-productive and reproductive performances of local laying hens. Egyptian Poultry Science, 32(32): 201-215.

Mayo MA (2002). A summary of taxonomic changes recently approved by ICTV. Archive of Virology, 38(March):11655-11656.

Miller PJ, King DJ, Afonso CL and Suarez DL (2007). Antigenic differences among Newcastle disease virus strains of different genotypes used in vaccine formulation affect viral shedding after a virulent challenge. Vaccine, 25(41): 7238-7246.

DOI:https://doi.org/10.1016/j.vaccine.2007.07.017.

Moon SH, Lee I, Feng X, Lee HY, Kim J and Ahn DU (2016). Effect of dietary beta-glucan on the performance of broilers and the quality of broiler breast meat. AsianAustralasian Journal of Animal Sciences, 29(3): 384-389. DOI:https://doi.org/10.5713/ajas.15.0141.

OIE (2012). Newcastle disease. Chapter 2.3.14. OIE Manual of Standards for Diagnostic Tests and Vaccines, NB: Version adopted by the World Assembly of Delegates of the OIE in May 2012.

Park JBK and Craggs RJ (2011). Nutrient removal in wastewater treatment high rate algal ponds with carbon dioxide addition. Water Science and Technology, 63(8): 17581764. DOI:https://doi.org/10.2166/wst.2011.114.

Pulz O and Gross W (2004). Valuable products from biotechnology of microalgae. Applied Microbiology and Biotechnology, 65(6): 635-648. DOI:https://doi.org/10.1007/s00253-004-1647-x.

Raach-Moujahed A, Hassani S, Zairi S, Bouallegue M, Darej C, Haddad B, Damergi C. (2011). Effect of dehydrated Spirulina platensis on performance and meat quality of broilers. Research Opinions in Animal and Veterinary Sciences 1(8):505-509.

Rawat I, Ranjith-Kumar R, Mutanda T and Bux F (2011). Dual role of microalgae: Phycoremediation of domestic wastewater and biomass production for sustainable biofuels production. Applied Energy, 88 (10): 3411-3424. DOI:https://doi.org/10.1016/j.apenergy.2010.11.025.

Ross-Elizabeth G and Warren D (1990). The nutritional value of dehydrated, blue-green algae (Spirulina platensis) for $\begin{array}{llll}\text { poultry. } & \text { Poultry science, } 69 & \text { (5): } & \end{array}$ DOI:10.3382/ps.0690794.

Russell PH and Ezeifeka GO (1995). The Hitchner B1 strain of Newcastle disease virus induces high levels of $\mathrm{IgA}, \mathrm{IgG}$ and $\operatorname{IgM}$ in newly hatched chicks. Vaccine, 13(1), 61-66. DOI:https://doi.org/10.1016/0264-410X(95)80012-3. 
Shanmugapriya B, Babu SS, Hariharan T, Sivaneswaran S, Anusha MB and College CN (2015). Research Article Dietary Administration OF Spirulina Platensis As Probiotics on Growth Performance and Histopathology in Broiler Chicks. International Journal of Recent Scientific Research, 6(2): 2650-2653.

Streble H and Krauter D (2006). Das Leben im Wassertropfen. Mikroflora und Mikrofauna des Süßwassers. Ein Bestimmungsbuch. 1946 Abb., (Franckh-Kosmos) Stuttgart, p. 429.

Stephen P, Slocombe, Ross M, Thomas N, McNeill S and Michele S (2013). Stanley Arapid and general method for measurement of protein in micro-algal biomass. BioresourceTechnology, 29:51-57.

Vanthoor-Koopmans M, Wijffels RH, Barbosa MJ, Eppink MHM. (2013). Biorefinery of microalgae for food and fuel. Bioresource Technology, 135: 142-149. DOI:https://doi.org/10.1016/j.biortech.2012.10.135.
Wu X, Ouyang H, Duan B, Pang D, Zhang L, Yuan T and Li GP (2012). Production of cloned transgenic cow expressing omega-3 fatty acids. Transgenic Research, 21(3): 537543. DOI:https://doi.org/10.1007/s11248-011-9554-2.

Zhang B, Guo Y and Wang Z (2008). The modulating effect of $\beta-1,3 / 1,6$-glucan supplementation in the diet on performance and immunological responses of broiler chickens. Asian-Australasian Journal of Animal Sciences, 21(2): 237-244.

DOI:https://doi.org/10.5713/ajas.2008.70207.

Zhao W, Spatz S, Zhang Z, Wen G, Garcia M, Zsak L and Yu Q (2014). Newcastle Disease Virus (NDV) Recombinants Expressing Infectious Laryngotracheitis Virus (ILTV) Glycoproteins gB and gD Protect Chickens against ILTV and NDV Challenges. Journal of Virology, 88(15): 83978406. DOI:https://doi.org/10.1128/jvi.01321-14 